\title{
Meios de Obtenção de prova na fase Preliminar Criminal: consideraçốes SObre RECONHECIMENTO PESSOAL NO BRASIL E NA LEGISLAÇÃO COMPARADA
}

\author{
RAFAel Francisco França \\ Departamento de Polícia Federal - Brasil$$
\approx
$$

\begin{abstract}
RESUMO
O presente artigo tem por objetivo definir pontos de discussão sobre o reconhecimento pessoal dentro do contexto de obtenção de meios de prova no processo penal. Para tanto, serão conceituados os institutos tendo como ponto de partida a legislação brasileira, com especial atenção a questões práticas para, assim, destacar a situação de tais dispositivos na investigação criminal preliminar. Dentro do objetivo mencionado, serão expostas informações sobre os procedimentos adotados para o reconhecimento pessoal pelo sistema espanhol, pelo português, na Itália e outros países, com o que se espera, por comparação, concluir sobre a necessidade de mudanças na legislação pátria sobre tais assuntos.
\end{abstract}

PALAVRAS-CHAVES: argumentos de prova; reconhecimento pessoal; Legislação comparada (Espanha, Portugal e Itália).

\section{INTRODUÇÃO}

Em matéria de produção de argumentos de prova em sede de investigação preliminar, mais especificamente em sede de estudo das modalidades disponíveis, são diversos os problemas enfrentados. Muitos são os fatores determinantes desencadeados ainda na fase de inquérito, acarretando a necessidade de maior atenção aos procedimentos adotados.

Tendo como pano de fundo a necessidade de demonstração lógica do desenvolvimento da investigação criminal, torna-se imperioso definir que, como garantia, as formas e os meios pelos quais as provas são obtidos devem ser rigidamente obedecidos, sob pena de invalidade e de não utilização em Juízo. 
Assim, este trabalho trata sobre aspectos polêmicos de um dos mais importantes meios de obtenção de provas no processo penal, de polêmica estrutura e de conturbada aceitação pela doutrina e pela jurisprudência: o reconhecimento pessoal.

Percebe-se a necessidade de definição dos procedimentos adotados não só no Brasil, mas também em outros países para que, pela comparação, possam ser desmitificados alguns pontos tidos como conflitantes em decisões judiciais exaradas pelos tribunais superiores durante os últimos anos.

Importante citar que não há a pretensão de abordagem profunda aos temas, isso tendo em vista a necessária comparação dos institutos após breves definições. Deve ser também citado que, embora sejam analisados diferentes sistemas processuais, dar-se-á preferência ao estudo de elementos atinentes às fases investigatórias dos processos penais, estabelecidas as dificuldades em se delimitar se há ou não investigação durante a instrução da ação penal em tais sistemas.

Dessa forma, e para que sejam mais bem entendidos os pressupostos de definição e comparação estabelecidos, foram feitas divisões em tópicos e subtópicos de acordo com a proposta de estudo sobre os mencionados meios de obtenção de prova.

Torna-se necessário determinar, desde já, que a medida cautelar de reconhecimento pessoal durante a fase de investigação policial também se difere em diversos aspectos do reconhecimento feito já na fase processual, devendo ser observado que reconhecimento pessoal é prova irrepetível.

Nessa matéria podem ser encontrados diversos problemas a investigados e réus. Dentre eles, a exposição e o direito de não produzir provas contra si mesmos e a possibilidade de serem reconhecidos por fotografia, o que delimita o trabalho policial, torna a execução das medidas ainda mais carente de formalidades e determina a necessidade de preparo dos agentes responsáveis pela organização e execução das mesmas.

Por isso, optou-se por iniciar pela análise dos atos de reconhecimento pessoal na legislação brasileira, isso com o intuito de delimitar o campo de comparação com outras realidades em sistemas processuais, pelo que serão apontados os pontos em que pode avançar a coleta de tal prova. 
A sistemática usada pelo Código de Processo Penal para o desenvolvimento das sessões de reconhecimento demonstra não só a falta de detalhamento necessário à execução da medida, mas, também, atesta a possibilidade de realização sem a presença de advogado defensor, fato que pode macular os resultados e prejudicar a investigação.

Ao final, apresentar-se-ão comentários e conclusões sobre o tema, tido como central em matéria de busca por fontes de prova no processo penal brasileiro, mormente em sede de investigações policiais e em decorrências das análises comparativas efetuadas com base nas legislações de outros países.

\section{MEIOS DE OBTENÇÃO DE PROVA NA INVESTIGAÇÃO CRIMINAL PRELIMINAR}

No contexto apresentado pela investigação criminal preliminar, e levando-se em consideração a necessidade de estudo sobre as ferramentas de investigação aqui proposta, é necessário citar alguns pontos sobre meios de obtenção de provas durante a instrução de procedimentos policiais e preliminares em sede de apuração de delitos, devendo ser levado em consideração o valor probatório que pode ser alcançado por alguns deles.

Embora se tenha em mente que, segundo LOPES (2011), meio de prova pode ser definido como "a atividade pelo meio da qual se introduz no procedimento um elemento de prova.", é importante definir que, na fase de investigação policial ou preliminar penal não se tem, ainda, produção de prova, a qual somente ocorrerá no desenvolvimento de eventual ação penal. Por isso mesmo, segundo tal autora, a atividade em tela exige sempre a participação do juiz e das partes, isso com o dever de submissão ao contraditório, o que denota a possibilidade de produção antecipada quando possível.

Portanto, embora seja possível definir e até mesmo apontar indícios que levem ao reconhecimento e à autoria em sede de investigação preliminar, é necessário que, posteriormente, tais informações sejam filtradas pelo processo penal para que possam ser utilizadas em fundamentos de decisão e sentença. 
De acordo com GRINOVER (1997) ${ }^{1}$, a sequência de atos que são praticados, por exemplo, na medida de interceptação telefônica determinam melhor o que seria um meio de prova. Importante citar que as expressões "meio de prova" e "indício" podem ser consideradas como diversas para este trabalho. A primeira diz respeito ao procedimento de coleta ou separação de algum dado, objeto, documento, gravação etc., que, submetido ao contraditório, possa servir de fundamento à tomada de decisão pelo Juízo. Quanto à segunda, esta é relacionada ao procedimento de investigação, a algum dos itens acima citados que, embora ainda não submetidos ao contraditório, possam servir de base à investigação (indiciamentos, pedidos de interceptação telefônica, buscas e apreensões etc.).

Dessa maneira, o reconhecimento fotográfico precário em sede policial (indício-base a meio de obtenção de prova) pode dar azo ao reconhecimento pessoal como antecipação de prova ou, ao menos, como fator de embasamento da denúncia. A importância da atividade investigatória, portanto, supera o preconceituoso caráter de "mera peça de informações"2 para solidificar-se como período de coleta de meios para a delimitação do alcance da própria ação penal vindoura.

Para tanto, todavia, considera-se a necessidade de obediência à forma prevista na lei para que as atividades de investigação sejam desenvolvidas, para que, conforme será exposto em relação ao sistema processual de outros países, os resultados possam ser considerados como meio de prova.

\section{RECONHECIMENTO PESSOAL}

Após a ocorrência do delito, e como dever de coleta de todas as informações possíveis sobre os fatos em reconstrução, cabe ao investigador ouvir testemunhas, declarantes e informantes na tentativa de estabelecer a autoria.

1 p. 117. "Mas o termo "prova" não é unívoco. Em uma primeira acepção, indica o conjunto de atos processuais praticados para averiguar a verdade e formar o convencimento do juiz sobre os fatos. Num segundo sentido, designa o resultado dessa atividade. No terceiro, aponta para os "meios de prova". Podese, assim, distinguir entre fonte de prova (os fatos percebidos pelo juiz), meio de prova (instrumentos pelos quais os mesmos se fixam em juízo) e objeto de prova (o fato a ser provado, que se deduz da fonte e se introduz no processo pelo meio de prova).. Interessante notar que a autora em tela também menciona que: "(...). O resultado da interceptação - que e uma operação técnica - é fonte de prova. Meio de prova será o documento (a gravação e sua transcrição) a ser introduzido no processo.”. p. 174.

2 "Verifica-se, assim, que a expressão "mera peça" deveria ser excluída dos livros doutrinários, já que, como é cediço, todas as provas produzidas dentro desse importante procedimento investigativo, são, na maioria das vezes, apenas repetidas em Juízo." - CARVALHO, Paulo Henrique da Silva. A importância do inquérito policial no sistema processual penal. Disponível em http://www.advogado.adv.br/ artigos/2006/paulohenriquedasilvacarvalho/aimportanciainquerito.htm, acesso em 07/10/2012. 
Insta citar, nesse ponto, que o reconhecimento pessoal ou de coisas é meio de obtenção de provas em diversos sistemas processuais, sendo que as diferenças no modo como são desenvolvidos os atos determina a qualidade da prova produzida. Trabalha-se com duas variantes: tempo e memória.

Conforme CUTLER (1996) 3 , sessões de reconhecimento são consideradas importantes para a solução de investigações, sendo a forma mais comum de testemunho em julgamentos criminais. Todavia, é importante observar que há considerável possibilidade de erro se as sessões não forem desenvolvidas de maneiras a evitar dubiedade e imprecisões.

Sendo assim, nos termos do que aponta FERNANDES (2007), ainda é possível apontar ser comum nas legislações penais que uma espécie de reconhecimento seja regulada e este regulamento sirva para determinar como se dará outra modalidade. Ainda, aponta o mesmo autor para a necessidade em se seguir um rito para tal meio de obtenção de prova, o que fica prejudicado se for aplicado um modo para a sua realização a outro não previsto; é o que chama de irritualidade.

Dessa maneira, discutiu-se nas XX Jornadas Ibero Americanas de Direito Processual Penal, realizada em Málaga, Espanha, no ano de 2006, que, no caso brasileiro, em sendo realizado reconhecimento por meio de fotografia não haveria problema de atipicidade (tipo de reconhecimento) ou de irritualidade. Chega-se, portanto, à conclusão de que o problema, sim, reside no descumprimento do rito previsto, pois haveria coleta de prova típica por meio de rito diverso. Dessa forma, ficou evidente que o reconhecimento fotográfico é precário.

$\mathrm{O}$ ato de reconhecer, diga-se de passagem, é importante e necessário para a aproximação da vítima dos atos investigatórios. No entanto, e até pela carga de emoção envolvida no ato, torna-se ainda mais necessária a observância de cuidados elementares no desenvolvimento do ato de investigação em tela, eis que podem ser cometidos erros de considerável gravidade, sendo o principal deles o apontamento errôneo de autor de crime. Muitas vezes,

3 The criminal justice system recognizes that eyewitness testimony in general and eyewitness identification in particular play profoundly important roles in the apprehension, prosecution, and adjudication of criminal offenders. Police investigators rely heavily on eyewitness testimony in their initial investigation of a crime (Fisher \& Geiselman, 1992). Eyewitness identifications from photospreads and lineups are frequent occurrences (Brigham \& Bothwell, 1983; Goldstein, Chance, \& Schneller, 1991). And the eyewitness is probably the single most common form of witness in many criminal trials. The criminal justice system also acknowledges the influence that eyewitnesses have on trial outcomes. p. 6. 
pelo calor dos acontecimentos e pela necessidade de "vingança", equívocos cometidos na fase de investigação podem ser refletidos por anulações no processo penal. A investigação, portanto, seguirá para caminho diverso e haverá chance de fracasso na indicação de autoria.

Ademais, ressaltando-se a importância de tal procedimento, é possível definir que o reconhecimento é prova irrepetível (FERNANDES; ALMEIDA; MORAES, 2011, p. 20). Sendo dessa forma, não se pode simplesmente anular um ato de reconhecimento, haja vista que não se pode renovar tal sessão nos mesmos moldes já definidos. Ou seja, "não se reconhece o já reconhecido". Se não forem seguidos os ritos previstos, perde-se o valor probante do procedimento.

Dessa maneira, importa definir que se não forem seguidas regras para a execução das sessões de reconhecimento pessoal, grande se torna a possibilidade de se tornar inócua. Em determinados crimes, como naqueles em que a palavra da vítima e suas percepções sobre o crime são imprescindíveis para a elucidação e apontamento de autoria, o reconhecimento pessoal surge como meio de prova de inigualável valor. Por isso mesmo, deve ser revestido de estrita observação da forma prevista pela lei. (LOPES, 2011, p. 6-7) .

De tal modo, quer seja realizado de modo preliminar, por fotografias ou como antecipação de produção de meio de prova, o reconhecimento pessoal deve obrigatoriamente ser envolto em formalidades 5 .

4 "Um dos meios de prova previstos expressamente no Código de Processo Penal brasileiro é o reconhecimento de pessoas e coisas. O reconhecimento é meio de prova utilizado com a finalidade de obter a identificação de pessoa ou coisa por meio de um processo psicológico de comparação com elementos do passado. O reconhecimento tem a natureza jurídica de meio de prova. Realizado na presença do juiz e com a participação das partes, formará elemento de prova e poderá ser levado em consideração pelo julgador na sentença.."

5 Todavia, conforme GUIMARÃES, "As provas produzidas administrativamente que não podem ser repetidas em juízo, podem ser classificadas assim1: a) Prova integrante da instrução probatória por força de lei: perícia; b) Prova integrante da instrução probatória por força própria: documento em todas as espécies; c) Provas extraprocessuais passíveis de integrar o procedimento probatório por contraste de regularidade: reconhecimento de pessoas ou coisas e, busca e apreensão". GUIMARÃES, Maurício Henrique et all. Provas policiais insuscetíveis de repetição. Revista da Associação dos Delegados de Polícia do Estado de São Paulo. Marcos Antônio Gama (Coord.), São Paulo: ADPESP. Ano 19, n. 26, dez/99. p. 16. Bom notar que o item "c" será irrepetível a prova se for produzida com estrita observância aos preceitos legais aplicáveis à espécie, cuja regularidade será atestada na instrução probatória processual pela testemunha que acompanha sua produção, havendo, então, um contraste de regularidade, onde os relatos das testemunhas substituem o reconhecimento ou a busca e a apreensão. Trata-se, na verdade, de prova testemunhal o "reconhecimento" feito em Juízo sem as devidas formalidades. 
Todavia, cabe também considerar que, tratando-se de ato atinente à memória das vítimas e testemunhas, ainda assim é possível ter como resultado um equívoco ${ }^{6}$. Ainda, para piorar a situação, é possível determinar que não há preocupação em preservar o meio de obtenção de provas que representa o reconhecimento pessoal no sistema brasileiro, baseado na memória de vítimas, declarantes e testemunhas. (GIACOMOLLI; DI GESU, 2008)7

Tal assunto já era tratado no sistema estadunidense há tempos, haja vista que se trata de tema atinente também à Psicologia. A principal preocupação incide sobre a transmissão dos dados da testemunha/vítima à Polícia e a apresentação de tais dados perante a Corte. (JOHNSON, 1973, p. 2) ${ }^{8}$.

Nesse ponto, é também ponto de discussão o fator "tempo" na construção do reconhecimento pessoal e nos resultados que se esperam com a atividade. A separação entre o fato (intervalo de retenção do dado a ser memorizado), conjecturado com as informaçóes obtidas após o ocorrido, modifica a capacidade de resposta da testemunha ou da vítima sobre o que deve ser reconhecido.

6 Os erros em reconhecimentos pessoais têm causado condenações errôneas nos Estados Unidos. Conforme reportagem a seguir citada, os exames de ADN demonstraram que os condenados foram reconhecidos equivocadamente, o que já provocou mais de duzentas libertações de inocentes. A seguir, trecho da mencionada reportagem: In 1981, 22-year-old Jerry Miller was arrested and charged with robbing, kidnapping, and raping a woman. Two witnesses identified Miller, in a police lineup, as the perpetrator. The victim provided a more tentative identification at trial. Miller was convicted, served 24 years in prison, and was released on parole as a registered sex offender, requiring him to wear an electronic monitoring device at all times. Recent DNA tests, however, tell a different story: Semen taken from the victim's clothing - which could have come only from the perpetrator-did not come from Miller. In fact, when a DNA profile was created from the semen and entered into the Federal Bureau of Investigation's convicted offender database, another man was implicated in the crime. On April 23, 2007, Miller became the 200th person in the United States to be exonerated through DNA evidence. DNA should clear man who served 25 years. USATODAY JOURNAL, 4/23/2007 10:46 AM. Disponível em http:// usatoday30.usatoday.com/news/nation/2007-04-22-dna-exoneration-inside_N.htm, acesso em $23 / 10 / 2012$.

7 Vários são os fatores responsáveis pela deterioração da lembrança, sendo que os dois principais são: 1) o intervalo até a retenção (a diminuição da precisão da lembrança se deve ao esquecimento normal, o qual é mais rápido após a aquisição e antes da retenção, tornando-se mais lento em seguida) e 2) as informações obtidas após o ocorrido (durante o intervalo entre a aquisição e a retenção, ou mesmo após a retenção, a testemunha está exposta a novas informações sobre o acontecimento presenciado, por exemplo, por comentários posteriores de outras testemunhas, os quais criarão problemas para distinguir entre a informação original e a incorporada posteriormente).”.

8 Eyewitness identifications involve both psychological and procedural factors. The psychological aspects of eyewitness identification challenges human perception and question the human ability to distinguish one person from another. The procedural aspect is the questioning of: police procedures in obtaining eyewitness identification and the court procedures in presenting and interpreting eyewitness testimony. The main questions concerning the psychological aspect of eyewitness identification are: 1) the ability of a person to record characteristics of another; 2) the ability to retain these perceptions and; 3) the ability to communicate accurately and specifically these perceptions. 
Segundo estudo realizado por MARSHALL (1969), há três fatores que devem ser levados em consideração para a efetividade de reconhecimentos pessoais: 1 - percepção (modo pelos quais os eventos são interpretados pela testemunha/vítima levando-se em consideração seu estado de humor e emoções); 2 - lembranças: período de tempo decorrido entre o evento e a descrição feita pela testemunha/vítima sobre ele às autoridades, sendo que incidem sobre a memória desta outros fatores que podem influenciar na identificação; 3 - articulação: as mesmas palavras são usadas com significados diversos por pessoas diferentes. Por isso mesmo o artigo $6^{\circ}$ do Código de Processo Penal, em seu inciso VI, determina à autoridade policial que proceda ao reconhecimento de pessoas e coisas assim que tiver notícia e constatar a ocorrência de fato definido como crime, evitando-se, com isso, a influência do tempo sobre a memória de testemunhas e vítimas?.

Dessa forma, aduz-se que, conforme determinado por LOPES (2011), em recente tese de doutorado defendida na Faculdade de Direito da Universidade de São Paulo, "quando há procedimento estabelecido para a prática de algum meio de prova, este dever respeitado, sob pena de se atentar contra o devido processo legal e acarretar a nulidade do ato".

Tanto a interceptação telefônica, quanto o reconhecimento pessoal são atividades de investigação que devem ser enquadrados em tal concepção, sendo imperiosa a obediência às formas estabelecidas ${ }^{10}$. A obediência às formalidades é garantia de produção de melhores resultados, já que todo objeto de prova pode ser refutado na fase judicial da atividade.

Ainda, conforme o mesmo autor (ROBERTS, 2009), é possível apontar que nos Estados Unidos foi feita recomendação às forças policiais para que adotassem formas mais acuradas para o tratamento do reconhecimento pessoal.

Desta maneira, foi sugerida a substituição do reconhecimento simultâneo pelo sequencial, ou seja, os componentes da linha de reconhecimento não são postos às vistas da vítima/testemunha simultaneamente, mas de forma sequencial, entrando um após o outro no ambiente de reconhecimento.

9 Conforme pensam LOPES JR e DI GESU (2007): “As contaminações a que estão sujeitas a prova penal podem se minimizadas através da colheita da prova em um prazo razoável, objetivando-se suavizar a influência do tempo (esquecimento) na memória. (...)...

10 Conforme Andrew Roberts, professor da Universidade de Warwick (Reino Unido), e estudioso do assunto, reconhecimentos feitos a partir de procedimentos bem elaborados, obedecendo-se a sequência de atos e realizados o quanto antes são menos suscetíveis a erros. (ROBERTS, 2009). 
Se por acaso a vítima/testemunha apontar um dos reconhecendos como autor de delito, não terá acesso aos demais da linha, o que difere tal procedimento do "tradicional" (linha de reconhecimento simultâneo), haja vista que terá que tomar uma decisão a cada reconbecendo que entrar no ambiente de reconhecimento.

\section{É direito do investigado, caso concorde em participar da sessão} de reconhecimento, de ter todo aparato possível para que haja fidelidade nos resultados. Assim, conforme ROBERTS (2009) ${ }^{11}$, o acusado tem o direito de que a prova seja produzida pelo meio mais acurado, com maior precisão possível, não podendo o Estado alegar carência de meios ou tempo para não proceder dessa forma.

$\mathrm{Na}$ verdade, os modelos para realização das sessões de reconhecimento (simultâneo ou sequencial), oferecem vantagens e desvantagens. Em relação ao reconhecimento simultâneo, a vítima/testemunha pode comparar as características físicas de todos os componentes da linha, eleger aqueles que mantêm maior semelhança com o autor ${ }^{12}$. A partir daí, pode apontar qual deles, componentes da linha, assemelha-se ao culpado. Já no reconhecimento sequencial ${ }^{13}$, tal possibilidade inexiste, já que terá que tomar uma decisão em

11 Where identification is, or might become, a central issue in a case, must the police always use procedures which are thought to produce the most reliable identification evidence? In other words, does a suspect have a right to the most accurate identification procedures? One way of addressing the problem of finite resources is to claim that the suspect's right to the use of the most accurate identification procedures is a qualified right. Dworkin, for example, argues that an absolute right to the most accurate procedures for determining innocence and guilt would require the criminal justice system to have first call on the resources available to a government. Diversion of resources into the criminal justice system to give effect to this right would lead to a state of affairs in which there were insufficient resources to fund other aspects of governments' welfare obligations.

12 Simultaneous presentation of subjects allows the witness to compare the persons appearing in the procedure to one another. It is suggested that this might lead to the witness selecting the subject who bears the closest resemblance to the culprit, though that resemblance may not, in fact, be particularly close. The suspect may be identified on the basis that he is the "best candidate"

13 Because in the sequential lineup the witness is shown only one image at a time and is required to make a decision in relation to each image before the next is shown, the opportunity to compare subjects does not arise. Because intra-subject comparison is not possible, any identification is more likely to based on there being a close similarity in the suspect's appearance and the witness's recollection of the culprit. It has been suggested that, as identification of a suspect through a shallow relative judgment may amount to no more than speculation on the part of the witness, a higher rate of false identification might be expected. This kind of speculation on the part of the witness might be expected to lead to identification of suspects from time-to-time. If the opportunity to speculate is removed then the rate of accurate identification may fall. However, suppose further research were to reveal that the use of sequential lineups brought about a roughly equal reduction in the rate of false and accurate positive identifications; that its use would produce no net gain in procedural accuracy. Some might still advocate adoption of the sequential lineup on the grounds that its use would lead 
relação cada um dos que forem aparecendo à sua frente, podendo, inclusive, isentar o real autor por não reconhecê-lo, evitando, também, "falsos positivos”. No entanto, os resultados obtidos pelo sequencial são mais confiáveis, embora seja observado que há menor incidência de autores de crimes reconhecidos por tal método. Bom ser também notado que esta consequência é mais aceitável do que a indicação falsa de autoria pelas falhas do modelo simultâneo, o qual permite a escolha do "mais parecido".

Outro ponto interessante é relativo ao policial (ou policiais) responsável pela condução da sessão. De acordo com definição posta por Schuster $(2007)^{14}$, se o policial que conduz a sessão tem conhecimento de quem é o autor do delito dentre os que compõem a linha ou a sequência de reconhecimento, voluntária ou involuntariamente acabará por sugerir à vítima ou à testemunha que aponte este como o reconhecido ${ }^{15}$.

De tal modo, é interessante que a condução do reconhecimento seja feita por policiais que não conheçam o suspeito, o que fará com que os resultados sejam valorados de forma a embasar tomada de decisões em sede policial ou até mesmo em Juízo.

\subsection{Reconhecimento pessoal no sistema brasileiro}

De acordo com o que está disposto no artigo 226 e seguintes do Código de Processo Penal ${ }^{16}$, procede-se ao reconhecimento pessoal obedecen-

to an appropriate allocation of the risk of error between suspect and state. A reduction in the rate of accurate positive identifications might be viewed as a acceptable price for greater protection against the risk of false positive identification.

14 Typically, the law enforcement official or lineup administrator knows who the suspect is. Experts suggest that lineup administrators might - whether purposefully or inadvertently-give the witness verbal or nonverbal cues as to the identity of the suspect. For instance, if an eyewitness utters the number of a filler, the lineup administrator may say to the witness, "Take your time ... . Make sure you look at all the photos." Such a statement may effectively lead the witness away from the filler. In a "double-blind" lineup, however, neither the administrator nor the witness knows the identity of the suspect, and so the administrator cannot influence the witness in any way.

15 Neste ponto, são conhecidas as "sugestões" feitas no decorrer das sessões: "olhe mais uma vez", "tens certeza?", "quer que eu mande que se aproximem?", "deseja olhar este mais de perto?”

16 Art. 226. Quando houver necessidade de fazer-se o reconhecimento de pessoa, proceder-se-á pela seguinte forma: I - a pessoa que tiver de fazer o reconhecimento será convidada a descrever a pessoa que deva ser reconhecida; II - a pessoa, cujo reconhecimento se pretender, será colocada, se possível, ao lado de outras que com ela tiverem qualquer semelhança, convidando-se quem tiver de fazer o reconhecimento a apontá-la; III - se houver razão para recear que a pessoa chamada para o reconhecimento, por efeito de intimidação ou outra influência, não diga a verdade em face da pessoa que deve ser reconhecida, a autoridade providenciará para que esta não veja aquela; IV - do ato de 
do-se a uma sequência concatenada de atos, sem o que pode ser maculado o resultado da sessão de reconhecimento.

De tal modo, antes de ser regulada pelo mencionado dispositivo, a necessidade de reconhecimento é tratada, na verdade, pelo artigo $6^{\circ}$ do Código de Processo Penal. Em tal dispositivo, observa-se que, dentre as diligências que devem ser realizadas pela autoridade policial quando for até o local do crime, figura o ato de tratar sobre tal procedimento de modo preliminar. Assim, é nesse momento, se possível, que serão apontadas pelas testemunhas e pelas vítimas as características do autor do delito, fato extremamente relevante para a realização de outras diligências durante o inquérito.

Esta a principal razão para LOPES JR (2012) $)^{17}$ deduzir sobre a necessidade de estrito atendimento à forma prevista para a realização do ato.

De tal maneira, em sendo possível a indução da vítima em seu reconhecimento, considera-se necessária a reestruturação do procedimento ${ }^{18}$.

reconhecimento lavrar-se-á auto pormenorizado, subscrito pela autoridade, pela pessoa chamada para proceder ao reconhecimento e por duas testemunhas presenciais. Parágrafo único. O disposto no no III deste artigo não terá aplicação na fase da instrução criminal ou em plenário de julgamento. Art. 227. No reconhecimento de objeto, proceder-se-á com as cautelas estabelecidas no artigo anterior, no que for aplicável. Art. 228. Se várias forem as pessoas chamadas a efetuar o reconhecimento de pessoa ou de objeto, cada uma fará a prova em separado, evitando-se qualquer comunicação entre elas.

17 Trata-se de uma prova cuja forma de produção está estritamente definida e, partindo da premissa de que - em matéria processual penal - forma é garantia, não há espaço para informalidades judiciais. Infelizmente, prática bastante comum na praxe forense consiste em fazer reconhecimentos informais, admitidos em nome do livre convencimento motivado.

18 Observa-se que a possibilidade de erro existe e, quando estes ocorrem, tumultuam-se investigação e processo. Mesmo que sejam seguidos os ritos estabelecidos, ainda assim os resultados podem ser facilmente questionados. Como exemplo, observe-se o caso a seguir, amplamente divulgado pela mídia: GAZETA DO POVO. ON LINE. “Tragédia na Praia dos Amores em Caiobá. Disponível em http://www.gazetadopovo.com.br/vidaecidadania/conteudo.phtml?tl=1\&id=853179\&tit=Tra gedia-na-Praia-dos-Amores-em-Caioba, acesso em 02/10/2012. Em determinado trecho da matéria é possível compreender que as diligências policiais realizadas na sessão de reconhecimento, em tese, determinaram que a vítima reconhecesse pessoa diversa (O perito Rodrigo Soares Santos, contratado pela defesa do acusado de ter cometido o crime no Morro do Boi, em Matinhos, afirmou que a estudante Monik Pegorari de Lima foi induzida ao erro pela polícia no reconhecimento de Juarez Ferreira Pinto. Em entrevista coletiva na tarde desta quarta-feira $\left(1^{\circ}\right)$, Santos disse que a utilização de pessoas com biotipos físicos muito diferentes, fez com que a estudante associasse a imagem do criminoso com Juarez.). Exemplo de complicações geradas pelo mau uso de tal meio de obtenção de provas está disposto no conjunto de investigação gerado pelo crime cometido contra Monik Pegoraro de Lima e seu namorado Osíris Del Corso em 31 de janeiro de 2009, conforme fatos amplamente divulgados pela mídia. Mesmo que não se tenha a pretensão de avaliar a execução de atos de investigação no decorrer de tal procedimento, realizado pela Polícia Civil paranaense, é possível perceber pela leitura de matérias veiculadas que penderam dúvidas sobre a regularidade do resultado de reconhecimentos pessoais efetuados pela vítima Monik. Segundo peritos contratados pela defesa de Juarez Ferreira Pinto, apontado como autor do delito, Monik teria sido induzida ao erro pela Polícia Civil. 
Tal "indução a erro" pode ser causada até mesmo se o procedimento for executado de acordo com as regras do Código de Processo Penal. Por tais regras, e conforme está disposto pelo artigo 226 do Código de Processo Penal, a testemunha ou a vítima que tiver de fazer o reconhecimento será "convidada"19 a descrever a pessoa que deva ser reconhecida. Daí deduz-se que, antes da sessão de reconhecimento pessoal, a testemunha ou a vítima deve fornecer características físicas e do traje do suspeito, com o que vai ser preparada a sessão de maneiras a deixar que os componentes sejam trajados todos de maneira mais parecida possível ${ }^{20}$.

Em seguida, pela regra do inciso II, a pessoa a ser reconhecida deve ser colocada, se possivel, ao lado de outras que possuírem semelhança com ela. A partir daí, o reconhecedor deve ter acesso ao grupo e, caso seja possível, apontar quem deva ser reconhecido dentre os presentes.

Bom ser citado que, nos termos dos artigos 227 e 228 do Código de Processo Penal, o mesmo rito aplicado ao reconhecimento pessoal deverá ser seguido para objetos a serem reconhecidos. Além disso, se houver mais de um reconhecedor, deverão ser separados para que não se comuniquem, não sendo esclarecido se antes ou depois das sessóes.

O inciso III do artigo 226 determina que se o reconhecedor demonstrar estar intimidado pela presença do suspeito será providenciado que este último não o veja durante a sessão. Tal dispositivo indica que a testemunha ou a vítima demonstraram ou alegaram temor ou receio de participarem da atividade se puderem ser vistas pelas pessoas a serem reconhecidas. Deve ser levado em conta que, na fase judicial, provavelmente não será possível determinar que o denunciado, o réu, fique alheio à identidade do reconhecedor, o que causa problemas de toda ordem na sequência dos atos.

19 Pode a vítima se recusar a participar de sessão de reconhecimento na fase de investigação? Sim. Do mesmo modo que o investigado não é obrigado a comparecer a tal sessão, também à vítima assiste o direito de não participar de reconhecimentos pessoais ou fotográficos. Todavia, em relação às testemunhas há o dever de comparecer e participar, embora seja bastante temerário o comparecimento forçado de reconhecedores pela possibilidade de ocorrência de resultados diversos dos esperados. Desse modo, fica dito que reconhecimento pessoal é ato de caráter voluntário.

20 Dessa maneira, não se podem colocar quatro homens com barba e cabelos compridos ao lado de um com cabelos curtos e sem barba, ainda mais se, por exemplo, a vítima disser que o autor do crime tinha estas características. Tal situação pode induzi-la em erro e acarretar a desconsideração dos resultados. Ou seja, ela será induzida a reconhecer o componente que estiver trajado ou de características físicas mais próximas daquele que traz em mente. 
Assim, a experiência demonstra que, mesmo que haja o reconhecimento pessoal na fase policial, respeitando-se as formalidades previstas no referido artigo, a situação tende a mudar quando, colocada frente a frente do réu, a vítima ou a testemunha são "convidadas" a novamente reconhecê-lo no Juízo. Dois são os fatores que influenciam o reconhecimento nesta segunda fase: o tempo decorrido entre o primeiro reconhecimento e a audiência judicial, algumas vezes de meses ou anos, e o temor em proceder ao reconhecimento ao olhar no rosto do denunciado, muitas vezes algemado perante o $J_{u i ́ z o}{ }^{21}$ ou, ainda pior, já solto, podendo ter encontrado com o reconhecedor na entrada do Fórum ou no corredor de espera.

Tal entendimento também é compartilhado por LOPES (2011) ${ }^{22}$, quando assevera a necessidade de produção antecipada de prova no reconhecimento pessoal na fase de investigação preliminar.

Ou seja, há problemas a serem resolvidos no procedimento adotado pelas polícias e pelo Poder Judiciário no Brasil23 ${ }^{23}$ quanto ao sistema de reco-

21 Deve ser ainda levado em conta que, muitas vezes e quando o réu está solto, testemunha, vítima e familiares aguardam pelo "pregão" no saguão do fórum, o que já determina a temeridade em participar de reconhecimentos, haja vista que não são separados dos demais presentes.

22 A partir do momento que o reconhecedor teve contato com a pessoa a ser reconhecida, a imagem guardada na memória influirá no segundo reconhecimento. Assim, estará o ato viciado. É, portanto, meio irrepetível de prova. Assim, deve sempre ser produzido com todas as cautelas e observando o procedimento existente em lei para sua realização (arts. 226 e ss. do Código de Processo Penal). Em resumo, por somente ser produzido uma única vez, para que forme elementos de prova, deve ser realizado de forma perfeita, respeitando rigorosamente o procedimento legal e sempre na presença das partes e do juiz, em respeito ao princípio do contraditório. É também um meio de prova urgente e, por isso, deve ser realizado antecipadamente. Levando em conta a influência que a memória produz no reconhecimento, deve-se refletir o caráter de urgência existente na sua produção. $\mathrm{O}$ reconhecimento deve ser um dos primeiros atos de investigação de um fato criminoso, pois, para a sua adequada realização, exige-se que o sujeito ativo recorde muito bem a imagem da pessoa ou da coisa envolvida.”. Ainda assevera tal autora: "Em resumo, tendo em vista que o reconhecimento se trata de um meio de prova irrepetível, pois somente pode ser produzido uma vez, deve sempre ser realizado de acordo com o procedimento previsto em lei e com a participação das partes e do juiz, em respeito ao princípio constitucional do contraditório. Por ser meio de prova urgente, tendo em vista a influência negativa que o tempo acarreta na memória, deve ser realizado o mais rápido possível, preferencialmente na fase de investigação, antecipando-se a sua produção, com respeito ao rito e com a participação das partes e do juiz.

23 Conforme entendimentos jurisprudenciais do Superior Tribunal de Justiça-STJ, é possível determinar que ainda se está bastante distante de atendimento ao que determina a Constituição Federal em sede de direitos e garantias fundamentais. Somente como exemplo, a ementa de uma das decisões: "PROCESSUAL PENAL. HABEAS CORPUS PREVENTIVO SUBSTITUTIVO DE RECURSO ORDINÁRIO. HOMICÍDIO. RECONHECIMENTO PESSOAL. DIREITO AO SILÊNCIO. AUSÊNCIA DE VIOLAÇÃO. PROVIDÊNCIA PROBATÓRIA FACULTADA AO JUIZ. LIVRE CONVENCIMENTO. 1. A jurisprudência desta Corte é firme no sentido de que o reconhecimento pessoal não é obrigatório, ficando ao prudente arbítrio do Juiz da causa a necessidade 
nhecimento pessoal, devendo ser levado em conta que, em sede de crimes patrimoniais e contra a liberdade sexual, a prova por tal meio é muitas vezes essencial para a formação de culpa.

As modificações deduzidas pela doutrina são, portanto, necessárias e urgentes, o que pode ser feito ainda no Projeto do Novo Código de Processo Penal, em trâmite no Congresso Nacional. No entanto, conforme aduz LOPES JR (2009), as previsões não são favoráveis ${ }^{24}$.

Em virtude da carência de doutrina especializada sobre o tema, e pela simples repetição do que determina superficialmente a lei, é possível apontar que, como indicado acima por LOPES JR., se já não se tem disciplina

de realização dessa diligência. Precedentes do STJ e STF. 2. Habeas corpus conhecido e ordem denegada. (HC 164.870/SP, Rel. Ministro ADILSON VIEIRA MACABU (DESEMBARGADOR CONVOCADO DO TJ/RJ), QUINTA TURMA, julgado em 21/06/2012, DJe 03/08/2012).." E outra: "PROCESSO PENAL. HABEAS CORPUS. ROUBO CIRCUNSTANCIADO. RECONHECIMENTO PESSOAL. VÍCIO. SUPERVENIENTE RECONHECIMENTO JUDICIAL. EIVA SUPERADA. REGIME INICIAL FECHADO. MOTIVAÇÃO: ELEMENTOS CONCRETOS. ILEGALIDADE: AUSÊNCIA. 1. Resta superada a alegação de vício em reconhecimento pessoal, levado a cabo em sede policial, diante de congênere providência regularmente realizada em juízo. 2. Encontra-se motivada a sujeição ao regime inicial fechado quando alicerçado em elementos concretos, a despeito destes não terem sido empregados na fixação da pena-base, fixada no mínimo legal. 3. Ordem denegada. (HC 152.988/SP, Rel. Ministra MARIA THEREZA DE ASSIS MOURA, SEXTA TURMA, julgado em 02/02/2012, DJe 15/02/2012).

$24 \mathrm{O}$ reconhecimento de pessoas e coisas está previsto atualmente no art. 226 e ss. do CPP, e pode ocorrer tanto na fase pré-processual como também processual. No anteprojeto de reforma do CPP, o reconhecimento está regrado nos arts. 191 a 193, sendo o ponto nevrálgico estabelecido no art. 191. Basta uma rápida comparação para ver que não há nenhuma evolução ou reforma digna de nota. Os velhos problemas persistem: quantas pessoas devem participar do ato de reconhecimento? E a problemática lacuna em torno do "reconhecimento" por fotografias, será resolvida? Eo reconhecimento que dependa de outros sentidos, como o acústico, olfativo ou táctil, quando será disciplinado? No anteprojeto do CPP, nada consta.". LOPES JR, Aury. Reforma processual penal e o reconhecimento de pessoas: entre a estagnação e o grave retrocesso. Boletim IBCCRIM : São Paulo, ano 17, n. 200, p. 16-17, julho 2009. Ainda, interessante observar o que vem sendo aprovado no Anteprojeto de Reforma do Código de Processo Penal quanto a tal matéria: Seção IV. Do Reconhecimento de Pessoas e Coisas e da Acareação. Art. 191. Quando houver necessidade de fazer-se o reconhecimento de pessoa, proceder-se-á da seguinte forma: I - a pessoa que tiver de fazer o reconhecimento será convidada a descrevera pessoa que deva ser reconhecida; II - a pessoa, cujo reconhecimento se pretender, será colocada ao lado de outras que com ela tiverem qualquer semelhança, convidandose quem tiver de fazer o reconhecimento a apontá-la; III - a autoridade providenciará para que a pessoa a ser reconhecida não veja aquela chamada para fazer o reconhecimento; IV - do ato de reconhecimento lavrar-se-á auto pormenorizado, subscrito pela autoridade, pela pessoa chamada para proceder ao reconhecimento e por 2 (duas)testemunhas presenciais. $\mathrm{V}$ - no reconhecimento do acusado será observado o disposto no art. 265, \$40. Parágrafo único. O disposto no inciso III deste artigo não terá aplicação na fase da instrução criminal ou em plenário de julgamento. Art. 192. No reconhecimento de objeto, proceder-se-á com as cautelas estabelecidas no artigo anterior, no que for aplicável. Art. 193. Se várias forem as pessoas chamadas a efetuar o reconhecimento de pessoa ou de objeto, cada uma fará a prova em separado, evitando-se qualquer comunicação entre elas. 
para a realização de reconhecimentos pessoais (e fotográficos), quiçá quanto aos que necessitam ou dependem de outros sentidos para serem realizados (acústicos, olfativos ou tácteis). O Código de Processo Penal fala apenas em "pessoas e coisas", não tendo ainda definição sobre demais meios de gravação de imagem, como é possível observar no sistema processual português.

Outra questão interessante é a falta de regramento a ser seguido na sessão de reconhecimento em si, ou seja, antes, durante e após o ato de obtenção do meio de prova. Não se exige número mínimo de pessoas (somente deduz-se que sejam exigidas duas outras além do suspeito), sequências de entrada dos "reconhecendos" no local a ser utilizado para a sessão de reconhecimento $^{25}$, condições de repetição do ambiente, das vestimentas e, no mínimo, das características físicas do suspeito ${ }^{26}$, presença do advogado do reconhecido, prévia comunicação ao Juízo, à defesa e ao representante do Ministério Público para a realização das sessões, isso dentro outros pontos considerados

25 No que tange ao local em que são realizadas as sessões de reconhecimento, tal ponto de discussão mereceria estudo mais aprofundado para que fosse possível repetir com a maior fidelidade possível o ambiente em que o reconhecedor captou a imagem, a voz ou algum ponto característico do autor do delito. No entanto, o que se vê nas Delegacias de Polícia e nas unidades da Polícia Militar pelo Brasil é crucial para entender os motivos pelos quais o reconhecimento pessoal vem sendo atacados como meio de obtenção de prova pelos estudiosos do Direito Penal. São muito comuns reconhecimentos pessoais feitos com um só "reconhecendo" (por óbvio, o suspeito), com ele algemado, trajando roupas e com semblante de quem está recolhido ao cárcere (sapatos sem cadarços, sem cinto nas calças, cabelos despenteados, barba por fazer, camisa abotoada até o colarinho etc.) ou completamente diferente em sua aparência dos demais. Além disso, são comuns reconhecimentos feitos através de frestas de portas, por buracos em placas de compensado, por "olhos mágicos" de portas de gabinetes, por persianas ou pelas cortinas da sala do cafezinho, sem iluminação e sem as mínimas condições de reprodução de ambientes que se exigem em tal assunto.

26 Quanto às características físicas e de identificação do suspeito, já se decidiu que a vítima deve relatar algo que possibilite minimamente o reconhecimento do suspeito como autor do crime. Assim: "Número: 70050185339. Tribunal: Tribunal de Justiça do RS. Seção: CRIME. Tipo de Processo: Apelação Crime. Órgão Julgador: Sexta Câmara Criminal. Decisão: Acórdão. Relator: Aymoré Roque Pottes de Mello. Comarca de Origem: Comarca de Tramandaí. Ementa: AC No. 70.050.185.339 AC/M 4.074 - S 30.08.2012 - P 67 APELAÇÃO CRIMINAL. ROUBO MAJORADO. TESE RECURSAL ABSOLUTÓRIA CENTRADA NA AUSÊNCIA DE PROVA SUFICIENTE PARA A CONDENAÇÃO. ACOLHIMENTO. INCIDÊNCIA DO PRINCÍPIO HUMANITÁRIO DO IN DUBIO PRO REO (ART. 386, INC. VII, DO C.P.P.). ABSOLVIÇÃO. A única prova existente contra o réu no processo reside no reconhecimento pessoal feito pela vítima direta do fato, única que teve contato com o assaltante. Ocorre que a vítima afirma não ter visto o rosto do autor do fato, jamais tendo apontado qualquer característica física dele que possibilitasse o reconhecimento. Forma do ato de reconhecimento que pode ter gerado indução do reconhecedor, pois o réu foi colocado sozinho na sala logo após ter sido preso em razão de outro processo. Prova frágil para embasar a condenação, quando desacompanhado de qualquer outro elemento de prova a confirmar o aponte. Absolvição do réu que se impõe. APELO PROVIDO. (Apelação Crime N ${ }^{\circ}$ 70050185339, Sexta Câmara Criminal, Tribunal de Justiça do RS, Relator: Aymoré Roque Pottes de Mello, Julgado em 30/08/2012). Data de Julgamento: 30/08/2012”. Disponível em http://www1. tjrs.jus.br/busca/?q=\%22reconhecimento+pessoal\%22\&tb=jurisnova, acesso em 07/10/2012. 
importantes para melhor aceitação dos resultados como meio de obtenção de prova na investigação.

Por fim, interessante citar que o investigado, indiciado ou réu não é obrigado a participar de sessões de reconhecimento pessoal, haja vista o exercício do direito a não produzir prova contra si mesmo ${ }^{27}$.

Esta também uma das razões pelas quais o reconhecimento fotográfico é tido como de precário valor, devendo necessariamente ser cotejado com outras provas para que possa obter maior respaldo. Também vale tal assertiva para os reconhecimentos feitos por imagens de câmeras de segurança, circuitos internos de televisão, celulares etc., não se podendo admitir regras menos rígidas para procedimentos tão importantes.

De acordo com LOPES JR (2012), o reconhecimento fotográfico somente pode servir como ato preparatório para o reconhecimento pessoal, sendo vedado seu uso como um substitutivo àquele ou, ainda, como prova inominada (admissão do auto de reconhecimento fotográfico sem o posterior auto de reconhecimento pessoal).

O referido autor deixa claro que o reconhecimento fotográfico somente pode ser utilizado em duas oportunidades, quais sejam, de forma direta, com o suspeito ou imputado presente (caso concorde em participar do ato), e de forma indireta, haja vista o suspeito ou imputado não estar presente. No primeiro caso, inclusive, seria possível substituir a descrição referida no inciso I do artigo 226 do Código de Processo Penal pela fotografia reconhecida.

Ademais, também se faz necessário observar que não se pode substituir um modo de produção de prova (reconhecimento pessoal), por outro (reconhecimento fotográfico) quando os procedimentos para a formação dos resultados são tão diferentes. Na verdade, segundo Fernandes, Almeida Moraes (2011), busca-se burlar a disciplina legal do meio de prova que poderia ter sido adotado, o que acarreta vício de origem e, se for usado na instrução, vício processuall ${ }^{28}$.

27 SAAD (2004) diz que "Portanto, além de calar-se, negando-se a declarar, ou até mentir, pode também o acusado não contribuir para a atividade probatória levada a cabo pelos órgãos de investigação. $\mathrm{O}$ acusado não pode ser compelido a declarar nem a participar de qualquer atividade que possa porventura incriminá-lo ou prejudicar sua defesa.”.

28 Tratando sobre a citada substituição de prova, os autores dizem que "Também há referências à ocorrência de substituição em casos de reconhecimento. Assim, substitui-se o reconhecimento pessoal pelo fotográfico, quando o primeiro não pode ser realizado. Em juízo, substitui-se o reconhecimento 
Questôes interessantes surgem quando a discussão avança para elaboração de retratos falados e manipulação de fotografias de suspeitos para submissão a reconhecimentos fotográficos. Ainda, é necessário tecer comentários sobre álbuns de fotografias (agora, digitalizados) e oportunidade para fotografar suspeitos na fase de investigação.

Desse modo, é possível confeccionar retratos falados atualmente com o uso de softwares avançados, em nível bastante diferente dos antigos desenhos à mão. Tal diligência não pode ser comparada a uma sessão de reconhecimento fotográfico, mas ao estabelecimento de perfil de suspeitos a serem procurados e investigados pela Polícia.

Assim, não há interferência no contexto apresentado se o perito incluir boné, chapéu, bigode, óculos escuros etc., para que a descrição da vítima/testemunha aproxime-se ao máximo do que mantém em sua memória acerca do autor do delito. $\mathrm{O}$ estabelecimento de padrões de autoria é elementar para refinamento dos atos de investigação, restringindo o campo de trabalho e economizando meios para a solução do caso. Se houver semelhanças entre o retrato falado e o suspeito indiciado, tal resultado interessa, entretanto, somente à investigação.

A situação é modificada quando se aborda a segunda questão. Tendo em vista a possibilidade de reconhecimento fotográfico como meio preparatório para o reconhecimento pessoal, e levando-se em consideração as peculiaridades do ato criminoso (por exemplo, se o autor do assalto utilizava óculos, se o estuprador estava de gorro, se o sequestrador usava barba etc.), seria possível manipular fotografias do suspeito para que sejam mostradas no reconhecimento?

No que diz respeito ao reconhecimento pessoal, Lopes Jr. (2012, p. 685) traz exemplo do ordenamento alemão em que há possibilidade de modificação do aspecto físico do imputado (cortar-lhe os cabelos, raspar barba etc.) para que participe da sessão de modo aproximado à descrição da vítima/ testemunha ${ }^{29}$, o que não é permitido pela legislação brasileira.

pelo apontamento do acusado na audiência pela testemunha. Mencionam Rosa Maria Rocha e Teresa Alves Martins crítica à admissão, pelo Supremo Tribunal de Portugal, de reconhecimento atípico efetuado em audiência de julgamento sem observância dos formalismos legais para o reconhecimento de pessoas, com invocação do princípio da livre apreciação da prova, embora o Tribunal Constitucional tenha afirmado a impossibilidade de se admitir como prova reconhecimento feito sem a observância dos requisitos legais. Lembra-se de que o reconhecimento na audiência tem sido considerado em algumas decisões como meio de identificação e não de reconhecimento, não submetido, por isso, ao regime deste. (p. 38).

29 Interessante notar que, no Brasil e em alguns casos, o indiciado/réu modifica suas características físicas 
Mas o que se deseja é abrir discussão sobre a possibilidade de modificação de fotografias do suspeito para que sejam mostradas no ato (incluir um boné, retirar o bigode, envelhecê-lo etc.). Dessa forma, e de acordo com o que foi dito pela vítima/testemunha, seria possível definir que todas as fotografias que forem mostradas tenham o adereço, ou estejam de bigode, ou com cabelos loiros, o que definirá aproximação com a descrição original.

Não há restrição às modificações em tela, haja vista que podem até mesmo servir para substituir o apontamento de características pela vítima/ testemunha antes da sessão de reconhecimento pessoal, conforme apontado por LOPES JR (2012, p. 683-684). Todavia, não poderá manter valor se não for realizada sessão de reconhecimento pessoal ${ }^{30} \mathrm{em}$ seguida.

No que diz respeito aos álbuns de fotografias, estes atualmente e em sua quase totalidade estão contidos em programas computacionais, com o que são agrupadas as fotos de suspeitos, de presos e indiciados pelo delito cometido, pela região em que atuam, pelo grupo criminoso do qual fazem parte etc., tudo com o objetivo de facilitar a identificação de ações criminosas perpetradas.

Bom ser comentado que a grande maioria das forças policiais toma tais providências, não sendo incomum a identificação de suspeitos por vítimas/testemunhas por tais padrões.

Ainda, tais fotografias podem ser obtidas por atos de identificação criminal, conforme dispõe a Lei $n^{\circ} 12.037 / 2009$, ou pelos bancos de dados disponibilizados aos órgãos policiais, os quais contêm dados de registros de identidade, de carteiras de habilitação, do sistema prisional. Interessante notar que a Internet também disponibiliza importantes ferramentas de identificação de suspeitos, haja vista a disseminação de redes sociais (Facebook, Orkut, LINKEDIN, etc.), consideradas como "fontes abertas" de investigação, sítios que armazenam fotos e dados interessantes para qualquer investigação.

aparentes durante o lapso de tempo decorrido entre o reconhecimento em sede policial e a audiência, situação em que novamente será visto pela vítima/testemunha. Assim, corta cabelos, pinta-os, raspa a barba ou deixa-a crescer, o que pode acarretar que não se confirme o reconhecimento. Assim, mais uma razão para que se realize produção antecipada de provas quando do reconhecimento pessoal, nos moldes do artigo $6^{\circ}$ do CPP.

30 Mas, e se o suspeito não concordar em utilizar um boné, por exemplo, no ato da sessão de reconhecimento pessoal? Mais uma vez tem que ser apontado que o reconhecimento pessoal é ato voluntário pelo sistema processual brasileiro, não se podendo obrigá-lo a modificar sua apresentação durante a sessão de reconhecimento. 
Portanto, não há ilegalidade na formação de bancos de dados de suspeitos para uso em sede policial, sendo questão de natureza técnica. O que não pode ocorrer é a indução a reconhecimentos ou, ainda, a desconfiguração do ato com a ausência de posterior reconhecimento pessoal.

\subsection{O reconhecimento pessoal na legislação comparada}

Pela proposta desse estudo, passa-se a citar as principais características dos sistemas de alguns países no que diz respeito ao reconhecimento pessoal, seja visual presencial ou por fotografias, isso em atendimento à ideia inicial de comparar os meios de obtenção de provas alienígenas com o que vige no direito processual brasileiro.

De antemão revela-se interessante mencionar que as legislações analisadas não dedicam muitos dispositivos ao reconhecimento de pessoas e coisas, modificando-se em maior grau no que tange ao momento em que são realizados os procedimentos e ao valor probatório dos resultados obtidos.

No entanto, já se nota a necessidade de adequação dos procedimentos aos meios tornados disponíveis pela tecnologia para gravação de imagens e sons, o que certamente será objeto de discussão nos tribunais superiores daqui para frente. Quer dizer, em virtude da grande quantidade de câmeras e de equipamentos de gravação de dados espalhados por todos os cantos das cidades, rodovias, shoppings, bancos, lojas etc., é possível concluir que, se forem utilizados como meio de apontamento preliminar de suspeitos, deve haver um procedimento para tanto, por minimamente regrado que possa ser.

Passa-se, então, ao estudo sobre os dispositivos sobre reconhecimento pessoal em sistemas processuais alienígenas, com o que se pretende deduzir como está a situação do instituto na legislação nacional através de quadro comparativo.

\subsubsection{Reconhecimento pessoal no sistema processual italiano}

Pelo que consta do Codice di Procedure Penale da Itália, há a previsão do que foi chamado de "verdadeiro procedimento preliminar ao reconhecimento” por LOPES JR (2012, p. 682). 
De tal modo, o reconhecimento no procedimento italiano segue as determinações de forma previstas no artigo 213 e seguintes do mencionado código, pelo que deverá o juiz convidar a vítima ou a pessoa a ser reconhecedora a descrever a pessoa a ser reconhecida. Neste ato, deverá descrevê-la, indicando todas características possíveis.

Importante mencionar que, por este sistema, a testemunha ou a vítima são questionadas acerca da possibilidade de já terem participado de algum outro "reconhecimento", ou seja, se já viram o suposto autor do delito por fotografia ou por imagens. A partir daí, será elaborada uma ata em que estarão presentes todos estes dados. Somente daí se seguirá a sessão propriamente dita. (BONILINI; CONFORTINI, 2012) $)^{31}$.

Portanto, no sistema processual penal italiano é possível a realização de sessão de reconhecimento para objetos, o que não é previsto como rito específico pelo artigo 226 do Código de Processo Penal brasileiro. Trata-se de importante meio de comprovação da verossimilhança de afirmações em sede de investigação preliminar, haja vista a possibilidade de reforço de hipóteses na formação dos resultados a serem apresentados ao Juízo.

Além disso, fica caracterizado que há meios de identificação por reconhecimento de pessoas (artigo 213 do CPP italiano), coisa (artigo 215 do mesmo código) ou de voz, som ou qualquer outra coisa que possa ser objeto de percepção sensorial (artigo 216 do CPP italiano) (TONINI, 2002, p. 182). Segundo TONINI (op. cit.), qualquer irregularidade cometida no desenvolvimento das sessões de reconhecimento acarretará dúvidas na idoneidade do que chamou de "resultado probatório".

Outro ponto a ser considerado é o número de pessoas que devem ser chamadas para compor a fila de "reconhecendos"32. Pelo que se depreende dos dispositivos do Código de Processo Penal italiano, são exigidas pelo menos duas pessoas para acompanhar o suspeito na exibição ao reconhecedor, devendo ser observado que devem ser fisicamente semelhantes a ele para os efeitos desejados. Ainda, devem manter tal semelhança também nas vestimentas.

31 "La ricognizzoni è quel complesso mezzo di prova finalizzato a La conferma de un ato conoscitivo: attraversso esso, a una persona che abbia visto un determinato individuo o abbia precepito con i propri una cosa si chiede di riconoscerla individuandola tra altre simili.".

32 Trata-se das pessoas que serão postas ao lado do suspeito para cumprimento do que determina a legislação. Todavia, não se encontra menção a este termo no sistema italiano, tampouco no nacional, sendo apenas utilizado no meio policial para facilitar o desenvolvimento do procedimento. 
Além disso, o suspeito pode escolher o local em que queira se posicionar dentre as demais pessoas para que participe da sessão, o que não é sequer citado no caso brasileiro. Ao ser obrigado a se posicionar em determinado local, é possível definir que o investigado passe a ser mais um objeto do que sujeito em tal fase, o que impede que exerça com plenitude seu direito à defesa ${ }^{33}$.

Em seguida à descrição detalhada da pessoa do autor do delito, ou de quem se queira como reconhecido, o reconhecedor será convidado a se retirar do local. Depois de tomadas as providências anteriores, o reconhecedor retorna à sala e, perguntado, aponta se reconhece algum dos presentes, sendo que, em caso positivo, deverá "precisar sua convicção".

Por fim, outra diferença a ser indicado diz respeito à possibilidade do acusado também ser chamado a efetuar um reconhecimento no sistema italiano. Todavia, como garantia fundamental, poderá exercer seu direito ao silêncio.

\subsubsection{Reconhecimento pessoal no sistema processual português}

O sistema processual penal português acolheu o reconhecimento pessoal no artigo 147 do $\mathrm{CPP}^{34}$, pelo que é possível definir as principais características de tal procedimento na legislação daquele país.

33 Interessante mencionar que, de acordo com a Ley de Procedimiento Policial (Ley n ${ }^{\circ} 18.315$ de 5 de julio de 2008 - Código de conducta para funcionarios encargados de hacer cumplir la ley), da República Oriental do Uruguai, naquele país também é possível a escolha pelo suspeito do local em que quer ficar na linha de reconhecimento (artigo 66, número 2).

34 Artigo 147. ${ }^{\circ}$ Reconhecimento de pessoas 1 - Quando houver necessidade de proceder ao reconhecimento de qualquer pessoa, solicita-se à pessoa que deva fazer a identificação que a descreva, com indicação de todos os pormenores de que se recorda. Em seguida, é-lhe perguntado se já a tinha visto antes e em que condições. Por último, é interrogada sobre outras circunstâncias que possam influir na credibilidade da identificação. 2 - Se a identificação não for cabal, afasta-se quem dever proceder a ela e chamam-se pelo menos duas pessoas que apresentem as maiores semelhanças possíveis, inclusive de vestuário, com a pessoa a identificar. Esta última é colocada ao lado delas, devendo, se possível, apresentar-se nas mesmas condições em que poderia ter sido vista pela pessoa que procede ao reconhecimento. Esta é então chamada e perguntada sobre se reconhece algum dos presentes e, em caso afirmativo, qual. 3 - Se houver razão para crer que a pessoa chamada a fazer a identificação pode ser intimidada ou perturbada pela efectivação do reconhecimento e este não tiver lugar em audiência, deve o mesmo efectuar-se, se possível, sem que aquela pessoa seja vista pelo identificando. 4 - As pessoas que intervierem no processo de reconhecimento previsto no n. ${ }^{\circ} 2$ são, se nisso consentirem, fotografadas, sendo as fotografias juntas ao auto. 5 - O reconhecimento por fotografia, filme ou gravação realizado no âmbito da investigação criminal só pode valer como meio de prova quando for seguido de reconhecimento efectuado nos termos do n. ${ }^{\circ} 2.6$ - As fotografias, filmes ou gravações que se refiram apenas a pessoas que não tiverem sido reconhecidas podem ser juntas ao auto, mediante o respectivo consentimento. 7 - $\mathrm{O}$ reconhecimento que náo obedecer ao disposto neste artigo não tem valor como meio de prova, seja qual for a fase do processo em que ocorrer. Código de Processo Penal português, disponível em http://www.pgdlisboa.pt/pgdl/leis/lei_mostra_articulado. php?nid=199\&tabela=leis, acesso em 07/10/2012. 
Conforme consta, o reconhecedor é também incitado a descrever com detalhes a pessoa a quem deva reconhecer, o que determina que seja ouvida em declarações antes da sessão de reconhecimento, fato que é também mencionado em seguida, eis que é também perguntada se já havia visto o suspeito antes e em que condições. Ademais, é parte do procedimento a elaboração de questões ao reconhecedor que reforcem ou não a credibilidade no resultado do reconhecimento.

A sequência da sessão de reconhecimento por esse sistema também é revestida de garantias inexistentes no sistema nacional. De acordo com o que está previsto pelo artigo 147 do Código de Processo Penal português, se o reconhecedor não der certeza sobre a identificação do suspeito, serão colocadas outras pessoas com características físicas semelhantes (traços físicos e roupas, por exemplo) para nova rodada de reconhecimento.

Importante observar que, de acordo com o mesmo dispositivo, se não forem seguidos os passos determinados por este dispositivo, o reconhecimento ou os resultados obtidos não poderão servir como meio de prova. Ainda, fica também indicado que, se a identificação for cabal já no primeiro contato, não serão colocadas outras pessoas com semelhanças físicas ao lado do suspeito, conclusão retirada da leitura do dispositivo em tela.

Assim, embora se tenha alegado que a legislação portuguesa possua regramentos mais evoluídos do que a brasileira na proteção das garantias fundamentais do investigado/suspeito, de testemunhas ou de vítimas, é imperioso também considerar que, de acordo com entendimentos jurisprudenciais encontrados sobre o tema em tribunais daquele país revelaram pouco ou nenhum avanço sobre os procedimentos adotados no Brasil em tal matéria.

Bom ser notado que, conforme entendimento jurisprudencial sobre a matéria pelo Tribunal da Relação de Coimbra, é possível afirmar que não se dispensa o reconhecimento pessoal realizado na fase do inquérito policial, não necessitando o ato ser reproduzido na esfera judicial (audiência em julgamento) ${ }^{35}$.

35 PORTUGAL. Tribunal da Relação de Coimbra. No Convencional: 486/07.2. GAMLD.C1 JTRC Relator: GOMES DE SOUSA Descritores: PROVA POR RECONHECIMENTO PROIBIÇÃO DE VALORAÇÃO DE PROVAS Data do Acordão: 05/05/2010. Votação: UNANIMIDADE. Tribunal Recurso: COMARCA DA MEALHADA Texto Integral: $S$ Meio Processual: RECURSO PENAL. Decisão: CONFIRMADA. Legislação Nacional: 147º, 355 DO CPP. Disponível em http://www.dgsi.pt/jtrc.nsf/c3fb530030ea1c61802568d9005cd5bb/55466d6aa2c66c848025772a 0035046f ?OpenDocument, acesso em 07/10/2012. 
Conforme se depreende do julgado acima mencionado, tampouco se exige em Portugal que se proceda ao novo reconhecimento de forma obrigatória na fase judicial, dito que, se acaso o juiz entendê-lo como necessário, deverá seguir as determinações do artigo 147 do Código de Processo Penal.

Ademais, percebe-se que o referido artigo determina que a semelhança física dos indivíduos que compõem a sequência para reconhecimento é fator de ordem para que a sessão tenha os efeitos de meio de prova (valor). Ou seja, conforme o julgado a seguir colacionado, embora não acarrete nulidade, o reconhecimento pessoal realizado sem atendimento aos preceitos do artigo $147 \mathrm{do}$ CPP em Portugal pode definir "uma maior fragilidade na livre apreciação que o julgador deve fazer das provas obtidas", podendo, inclusive, não ter valor algum.

Todavia, e de acordo com a Lei $\mathrm{n}^{\circ} 48 / 2007$, de 29 de agosto, foi regulado o reconhecimento por fotografia, por filmagens ou gravações no direito processual penal português, o que representa avanço em relação à legislação brasileira. Não é demais apontar que não raramente são apresentados indícios de participação de indivíduos através de fotografias ou de gravações de circuitos internos de segurança, o que traz problemas no ato da formalização de reconhecimentos por carência de disposições legais.

Dessa maneira, conclui-se que, também em Portugal, a efetividade do dispositivo em tela sofre sérias influências da estrita obediência à forma, o que pende para o descumprimento na fase pré-processual. Interessante ser observada a semelhança do menor valor (ou até mesmo desvalor) dado à sessão de reconhecimento realizada sem cumprimento das formalidades legais com o instituto da inutilizzabilitá, previsto pelo sistema processual italiano, conforme será tratado neste trabalho.

\subsubsection{Reconhecimento pessoal no sistema processual espanhol}

Nos termos do que está determinado pela Ley de Enjuiciamento Criminal (LECrim), em seu artigo 368 e seguintes, a função de identificação do acusado é "função típica da investigação preliminar, sem a qual não se pode produzir a acusação”. (LOPES JR., 2012, p. 681). De tal modo, a execução de "la diligencia de reconocimiento en rueda" é considerada inidônea para ser realizada em plenário ou em algum ato de juízo oral. 
A argumentação utilizada para tanto é baseada principalmente no tempo que geralmente decorre entre a ocorrência do fato delituoso, a realização de sessão de reconhecimento na fase preliminar e a realização de audiência em contraditório perante a autoridade judicial. Com relativa demora, é possível que a testemunha ou a vítima percam informações e memórias que seriam importantes para assegurar maior fidelidade a eventual reconhecimento pessoal realizado, com o que se determina a produção antecipada de prova em relação a tal meio.

Importa também ressaltar que, de acordo com o LO nº 04/1997, regulada a utilização de imagens captadas por câmeras de vigilância instaladas em lugares públicos por "Fuerzas y Cuerpos de Seguridad”, isso com a finalidade exposta por MARTÍNEZ et al. (1999, p. 481): "asegurar la convivencia ciudadana, la erradicación de la violencia y la utilización pacífica de las vias y espacios públicos, así como para prevenir la comisión de delitos, faltas e infracciones relacionados con la seguridad pública..

Determinam os autores em tela, ainda, que como resultado da observação de atos tidos preliminarmente como ligados a possível crime, tais forças policiais devem reter a gravação e encaminhá-la, em até setenta e duas horas ao Ministério Público ou ao Juízo para providências cabíveis. Não sendo possível a gravação, será elaborado um relatório com o resumo sobre o conteúdo das imagens e dos fatos averiguados pelos policiais para os mesmos fins acima citados.

No que diz respeito ao reconhecimento em si, a Ley de Enjuiciamiento Criminal estabelece, no artigo 369, os requisitos que devem ser atendidos para tal ato, ou seja, para que produza os efeitos desejados. Ademais, também foram construídos entendimentos jurisprudenciais que fornecem limites e reforçam os requisitos a serem cumpridos para tanto.

Sendo assim, segundo o SSTS de 02 de fevereiro de 1996, e como garantia constitucional, tornou-se recomendada a presença do juiz e do advogado nas sessões de reconhecimento. Ademais, conforme consta, a pessoa a ser reconhecida deve ter colocada a frente da reconhecedora ao lado de outras com ela fisicamente parecidas. O reconhecedor ficará postado em local em que não possa ser visto pelas pessoas que participam da sessão como possíveis reconhecidos. 
Em seguida, o juiz perguntará ao reconhecedor se, dentre as pessoas presentes na "rueda o en el grupo de personas" está a que fora referida nas declarações anteriormente prestadas. Ou seja, antes da sessão de reconhecimento, a testemunha ou vítima é ouvida em declarações, situação em que relatará as características físicas e demais detalhes sobre o autor do crime. Dessa forma, na sessão de reconhecimento apontará se ali está o responsável de acordo com suas anteriores declarações.

Importante notar que, pelos artigos 371 e 372 da LECrim, deve haver cuidado para que o autor do delito não modifique suas características físicas (por exemplo, raspe a barba ou pinte os cabelos de outra cor) ou use trajes diferentes no intuito de furtar-se ao reconhecimento. Fica encarregado o diretor do estabelecimento prisional para onde foi enviado possível detido pela guarda e conservação das roupas com que foi apresentado, isso para favorecimento e garantias durante possíveis sessões de reconhecimento.

Pelo sistema em tela, se forem vários suspeitos a serem reconhecidos, serão efetuadas quantas sessões forem necessárias, isso de modo separado. Por outro lado, se foram várias vítimas ou testemunhas para reconhecer um só suspeito, pode ser realizado um só ato.

O que resta a ser confirmado quanto ao reconhecimento no modelo espanhol é a característica que assume como prova de produção antecipada, como já mencionado. (DOMÍNGUEZ; SENDRA; CATENA, 1999, p. 380 ${ }^{36}$. Dessa maneira, deve ser observado que, de acordo com sentença publicada recentemente pelo Tribunal Superior de Justiça da Catalunha, em relação ao chamado Caso Banda Bing (SENTENCIA N ${ }^{\circ} 412$, en Barcelona a 29 de octubre de 2009. Francisco Javier Pauli Collado, Magistrado juez titular del juzgado Penal no 22 de Barcelona $)^{37}$, ficou determinado que:

En este punto se ha discutido por las defensas los reconocimientos realizados, planteando en algún momento que o bien hubo previa exhibición de fotografias, o bien lo que se reconoce es un dorsal y no

36 En muchas ocasiones, dado el tiempo que transcurre desde que ocurrieron los hechos hasta que se celebra el juicio, se hace prácticamente imposible que en éste pueda reconocerse a la persona que realizó los hechos. Por estas circunstancias la diligencia de reconocimiento en rueda puede ser absolutamente necesaria para la condena del inculpado, convirtiendo en uno de los casos que están reconocidos en la ley y en la jurisprudencia como de pruebas anticipadas o diligencias sumariales que producen en el juicio oral los mismos efectos que las pruebas de cargo

37 Disponível em http://www.poderjudicial.es/cgpj/es/Poder_Judicial/Tribunales_Superiores_de_ Justicia/TSJ_Cataluna/Sala_de_prensa/Archivo_de_notas_de_prensa/Sentencia_Bada_Bing, acesso em 04/10/2012 
una cara. Establece el Tribunal Supremo en diversas resoluciones de la que se destaca la de 29 de abril de 1997,nº 642-97, recurso 212-96 que la diligencia de reconocimiento en rueda constituye una especifica prueba sumarial que no se puede practicar en las sesiones del juicio oral por resultar atipica e inidónea. Igualmente ha reconocido la virtualidad de esa diligencia practicada en las dependencias policiales, a presencia de Letrado, cuando ha sido ratificada en el Juzgado de instrucción y posteriormente en el acto del juicio oral por la persona que ha intervenido en la misma, identificando, sin duda, como sucede en este caso, a los autores de los hechos enjuiciados. Asi se han manifestado, entre otras, las sentencias de 7 de octubre y 10 de diciembre de 1991 que declaran la validez de la diligencia de reconocimiento en rueda de detenidos practicada en Comisaria y en presencia de Letrado, como actividad probatoria de cargo, siempre que se cumplan las previsiones de los artículos 368 y siguientes de la Ley de Enjuiciamiento Criminal, y sea posteriormente ratificada en el acto del juicio oral.

Portanto, pelo que está disposto no trecho acima destacado, o reconhecimento por meio de exposição de fotografias foi considerado válido, isso com sua realização em sede policial. Todavia, tal reconhecimento foi depois realizado de forma pessoal e com a presença de advogado, fato que foi confirmado no contraditório do processo penal (no Juízo de Instrução e no Juízo Oral). Ou seja, no sistema espanhol, o reconhecimento pessoal ocorre em fase preliminar ao processo, ressaltando-se que deve ser confirmado visual e pessoalmente na fase judicial.

Todavia, considera-se importante definir que, conforme está disposto por RUIZ e QUIROGA (2012, p. 282) 38 , é necessário submeter este reconhecimento feito na fase preliminar ao "interrogatório cruzado", efetuado durante o processo sob o crivo do contraditório.

Por outro lado, é possível apontar a importância de tal meio de obtenção de prova para o processo penal espanhol, tendo em vista que é obrigatoriamente realizado na presença de advogado, não podendo acontecer de maneira informal como soe ocorrer na investigação preliminar no Brasil.

38 "La verdadera diligencia de identificación procesal, como pone de relieve la citada Sentencia de 19 de diciembre de 1994, es la prevenida en los artículos 368 y siguientes de la Ley de Enjuiciamiento Criminal. Practicada con las debidas garantías y en forma contradictoria con la presencia del Letrado del acusado sometido a reconocimiento en rueda, tal identificación pode valorarse si, comparecido en el Juicio Oral en reconociente, puede ser sometido al interrogatorio cruzado de las partes a tal punto, para satisfacer el principio o se aportan en otra forma válida, como puede ser su lectura en el caso de imposibilidad cierta de comparecencia del testigo.". 
No entanto, bom ser observado que, de acordo com entendimentos jurisprudenciais coletados junto ao sítio do TSE (Tribunal Superior de $E$ spaña $)^{39}$, não se despreza totalmente o reconhecimento feito em sede policial com a presença do advogado do suspeito reconhecido, mesmo que tal sessão tenha se dado por meio de mostra de álbum fotográfico, meio de reconhecimento utilizado por diversas forças policiais em vários países como forma de levantamentos iniciais de alvos de investigação ou seus cúmplices pela descrição inicialmente fornecida pela vítima ou pelas testemunhas. (RUIZ; QUIROGA, 2012, p. 282 $)^{40}$.

De tal maneira, mesmo que se tenha por incidental o reconhecimento fotográfico realizado preliminarmente ao reconhecimento pessoal, este último terá valor muito maior se forem atendidos os requisitos para a realização das sessões, sendo um deles a realização com presença de advogado do suspeito e dentro das regras estabelecidas pela legislação.

A exigência de cumprimento das formalidades previstas, portanto, é cotejada com a busca de suspeitos pela polícia, sem o que seria impossível dar conta de indivíduos a serem reconhecidos. No entanto, fica também indicado que, já tendo tido acesso à fotografia do investigado antes da sessão, por meio de consulta às fotos cadastradas pela polícia, o reconhecedor pode ser direcionado, mesmo que involuntariamente, a somente confirmar o reconhecimento de forma pessoal, ou seja, ao identificar o mesmo rosto da fotografia ou imagem que lhe fora mostrada com o que aparece pessoalmente a sua frente durante a sessão.

39 Roj: SAP M 12079/2012 Id Cendoj: 28079370072012100442 Órgano: Audiencia Provincial Sede: Madrid Sección: 7 No de Recurso: 327/2012 No de Resolución: 702/2012 Procedimiento: APELACIÓN Ponente: MARIA TERESA GARCIA QUESADA Tipo de Resolución: Sentencia. http://www.poderjudicial.es/search/doAction?action=contentpdf\&databasematch=AN\&referenc $\mathrm{e}=6479261 \&$ links $=\% 22327 / 2012 \% 22 \% 20$ MARIA $\% 20$ TERESA\%20GARCIA $\% 20$ QUESADA \&optimize $=20120830$ \&publicinterface $=$ true, acesso em 07/10/2012. Na decisão, em certo trecho, citou-se que "D) El valor de prueba de identificación no sufre merma alguna por el solo hecho de que el reconociente en ella hubiese también reconocido antes en álbum fotográfico exhibido por funcionarios policiales en el ámbito de su investigación, práctica que no contamina ni erosiona la confianza que pueden suscitar las posteriores manifestaciones del testigo, tanto en las ruedas de reconocimiento como en las sesiones del juicio oral".

40 Este também foi o entendimento exposto no julgado a seguir transcrito: "El valor de la prueba de identificación no sufre merma alguna por el solo hecho de que el reconociente en ella hubiese también reconocido antes en el álbum fotográfico exhibido por funcionarios policiales en el ámbito de su investigación, práctica que no contamina o erosiona la confianza que pueden suscitar las posteriores manifestaciones del testigo, tanto en las ruedas de reconocimiento como en las sesiones del Juicio Oral (STS $2^{a}$ - 822/2008 - 04/12/2008 - 818/2008 - EDJ2008253397-).". 
Portanto, mesmo no sistema espanhol, o reconhecimento pessoal é tido como diligência problemática, que exige redobrada atenção às formalidades e na sequência dos atos a serem praticados para que não se cometam equívocos que determinam a inconsistência dos resultados.

\section{CONSIDERAÇÕES FINAIS}

A busca por elementos de prova no processo penal começa pela indicação dos meios para sua obtenção na fase investigativa preliminar. Por isso, é necessário dar maior atenção ao que ocorre neste período, eis que os equívocos e irregularidades cometidos aqui são diretamente refletidos na qualidade da denúncia e, consequentemente, na instrução da ação penal.

Em matéria de reconhecimento pessoal, os dispositivos encontrados no sistema brasileiro deixam clara as carências de maiores formalidades para o desenvolvimento das sessões e até mesmo quanto ao momento em que devem estas serem desenvolvidas. O que deve balizar o desenvolvimento de tal diligência é o respeito ao direito ao silêncio e o de não produzir prova contra si mesmo. Por outro lado, deve-se ter em mente que, por vezes, o único elemento de convicção disponível é o que foi captado por câmeras, por fotos ou pelas memórias de vítimas e de testemunhas.

Deve-se também levar em conta que o ato de reconhecimento é procedimento irrepetivel. Assim, se houver reconhecimento, ainda que fotográfico, na fase procedimental preparatória, não se pode repetí-lo durante a instrução processual com a mesma validade. $\mathrm{O}$ simples contato com a fisionomia ou com os dados do suspeito já maculariam os resultados.

Por outro lado, também deve ser observado que a efetividade de tal meio de obtenção de prova tem estrita relação com o tempo. Assim, pertinente considerar o que já determina o artigo $6^{\circ}$ do Código de Processo Penal e determinar que, sendo possível, seja realizada produção antecipada de provas. Nesse contexto, é atribuição da Autoridade Policial determinar que se proceda ao reconhecimento de pessoas e coisas o quanto antes, o que também leva a crer que deva provocar a antecipação de produção de prova, evitando-se, com isso, alegações de falhas cometidas e de pressões sofridas por reconhecedores.

Conforme consta do que foi citado em relação aos sistemas processuais penais de legislações comparadas, é possível também definir que alguns 
dos vícios aqui existentes também são observados em outros países. Um deles, sem dúvida, é a possibilidade de admissão de reconhecimentos fotográficos realizados na fase de investigação quando da instrução processual, com posterior convalidação dos resultados obtidos em Juízo.

Observa-se que, apesar de servir de base para possível reconhecimento pessoal, o procedimento que utiliza fotografias para apontar suspeitos não foi devidamente regrado no sistema processual brasileiro. Ainda são utilizados álbuns de fotografias, muitas vezes em preto e branco, sem que o reconhecedor tenha opções a indicar dentro de fotos semelhantes.

Dessa forma, e a partir de reconhecimentos fotográficos realizados desta maneira, possivelmente a vítima ou a testemunha irão apontar como autor do crime o mesmo indivíduo do qual viram fotografia em sede policial. Portanto, se o reconhecimento fotográfico foi feito de maneira equivocada, contaminará o argumento de prova e nem mesmo a prova testemunhal poderá ser produzida em Juízo em relação ao mesmo suspeito de forma convincente.

Embora se diga que o sistema legal brasileiro contará em breve com novo Código de Processo Penal, em matéria de reconhecimento de pessoas e coisas nada se modificou até agora no projeto de lei. Trata-se de reprodução dos mesmos dispositivos do atual, não tendo sido contempladas situações inerentes à evolução dos meios de investigação, tais como reconhecimentos de sons, por meio de filmagens, etc.

Outro ponto a ser mencionado diz respeito à necessidade da presença de advogados de defesa e de representantes do Ministério Público durante as sessões de reconhecimento pessoal. Verifica-se que em outras legislações, a produção do reconhecimento alcança maior valor probatório quando realizada desta maneira, ou seja, ampliando-se a ampla defesa e, de certa forma, possibilitando-se o contraditório.

Portanto, o que deve ser levado em conta ao final deste estudo é que, embora de difícil produção, o reconhecimento ainda é um dos mais importantes meios disponíveis para que se prove algo na investigação criminal. E essa importância deve servir de base para que sejam modificados os dispositivos legais acerca do procedimento a ser seguido, possibilitando maior aceitação e acuidade de seus resultados. 
Rafael Francisco França

Delegado de Polícia Federal; Especialista em Ciências Penais pela PUC/RS; Especialista em Ciências Policiais e InvestigaÇão Criminal pela ANP/DPF; Mestrando em CiênCias CrimiNAIS PELA PUC/RS; Sócio do InStituto Brasileiro de CiênCias

Criminais - IBCCRIM.

E-MAIL: FRANCA.RFF@DPF.GOV.BR

\begin{abstract}
This article aims to define points of discussion of eyewitness recognition within the context of obtaining evidence in criminal proceedings. So it must be cited and studied institutes having as starting point the Brazilian law, with particular attention to practical issues thus highlight the use of such devices in preliminary criminal investigation. Within the mentioned objective this article will expose information on the procedures used for the recognition by the Spanish, the Portuguese, Italy and other countries legal systems, with the hopes that, by comparison, to conclude on the need for changes in legislation on such matters homeland.
\end{abstract}

KEYWORDS: Evidence; Eyewitness Recognition; compared Legislation (Spain, Portugal and Italy);

\title{
REFERÊNCIAS BIBLIOGRÁFICAS
}

ANSELMO, Márcio Adriano. LEUTÉRIO, Alex Pereira. A Interceptação das Comunicações Como Meio de Investigação. Monografia de conclusão (Pós-Graduação em Direito). Faculdade de Direito. Universidade de São Paulo. 2012.

ARANTES FILHO, Márcio Geraldo Britto. A Regulamentação do Sigilo das Comunicações Entre Pessoas Presentes e do Sigilo Profissional no Direito Processual Penal Chileno. Revista Brasileira de Ciências Criminais. n.80, Editora Revista dos Tribunais, Ano 17, setembrooutubro de 2009.

AVOLIO, Luiz Francisco Torquato. Provas Ilícitas: interceptações telefônicas, ambientais e gravações clandestinas. - 4. ed. rev. e ampl. - São Paulo : Editora Revista dos Tribunais, 2010.

BONILINI G., CONFORTINI M. - Codice di Procedura Penale

Commentato. Quarta edizione. Torino: Utet Giuridica. 2012.

BRASIL. Senado Federal. Comissão de Juristas Responsável pela Elaboração de Anteprojeto de Reforma do Código de Processo Penal. Anteprojeto de Reforma do Código de Processo Penal / 
Comissão de Juristas Responsável pela Elaboração de Anteprojeto de Reforma do Código de Processo Penal. - Brasília : Senado Federal, Subsecretaria de Edições Técnicas, 2009.160 p.

BRASIL. Poder Judiciário. Supremo Tribunal Federal. (HC 69818, Relator(a): Min. SEPÚLVEDA PERTENCE, Primeira Turma, julgado em 03/11/1992, DJ 27-11-1992 PP-22302 EMENT VOL-01686-02 PP-00201).

Poder Judiciário. Supremo Tribunal Federal. (Inq 2424, Relator(a): Min. CEZAR PELUSO, Tribunal Pleno, julgado em 26/11/2008, DJe-055 DIVULG 25-03-2010 PUBLIC 26-032010 EMENT VOL-02395-02 PP-00341).

. Poder Judiciário. Superior Tribunal de Justiça. HC 164.870/SP, Rel. Ministro ADILSON VIEIRA MACABU (DESEMBARGADOR CONVOCADO DO TJ/RJ), QUINTA TURMA, julgado em 21/06/2012, DJe 03/08/2012. Disponível em http://www.stj.jus.br/SCON/jurisprudencia/toc.jsp?tipo_visual izacao $=$ null \&livre $=\% 22$ reconhecimento + pessoal $\% 22 \& b=A C O R \#$ DOC4, acesso em 08/10/2012.

Poder Judiciário. Superior Tribunal de Justiça. HC 152.988/ SP, Rel. Ministra MARIA THEREZA DE ASSIS MOURA, SEXTA TURMA, julgado em 02/02/2012, DJe 15/02/2012. Disponível em http://www.stj.jus.br/SCON/jurisprudencia/toc. jsp?tipo_visualizacao $=$ null\&livre $=\% 22$ reconhecimento + pessoal $\% 2$ 2\&b=ACOR\#DOC4, acesso em 08/10/2012.

Poder Judiciário. Tribunal de Justiça do Estado do Rio Grande do Sul. Processo número: 70050185339. Tribunal: Tribunal de Justiça do RS. Seção: CRIME. Tipo de Processo: Apelação Crime. Órgão Julgador: Sexta Câmara Criminal. Decisão: Acórdão. Relator: Aymoré Roque Pottes de Mello. Comarca de Origem: Comarca de Tramandaí. Ementa: AC No. 70.050.185.339 AC/M 4.074 - S 30.08.2012.

CARVALHO, Paulo Henrique da Silva. A Importância do Inquérito Policial no Sistema Processual Penal. Disponível em http://www. advogado.adv.br/artigos/2006/paulohenriquedasilvacarvalho/ aimportanciainquerito.htm, acesso em 07/10/2012. 
COLLI, Maciel. Interceptações Telefônicas: uma análise sob o direito comparado da Itália, Espanha e Portugal. In Processo Penal Contemporâneo. Nereu José Giacomolli, André Machado Maya (Organizadores). Porto Alegre : Núria Fabris Ed., 2010.

CUTLER, Brian L. Mistaken Identification: the eyewitness, psychology, and the law. Brian L. Cutler, and Steven D. New York: Cambridge University Press, 1996.

DOMÍNGUEZ, Valentín Cortés. SENDRA, Vicente Gimeno. CATENA, Víctor Moreno. Derecho Procesal Penal. $3^{a}$ ed. - Madrid, Editorial Codex, 1999.

ESPANHA. Audiencia Provincial de Madrid. Roj: SAP M 12079/2012 Id Cendoj: 28079370072012100442 Órgano: Audiencia Provincial Sede: Madrid Sección: 7 No de Recurso: 327/2012 No de Resolución: 702/2012 Procedimiento: APELACIÓN Ponente: MARIA TERESA GARCIA QUESADA Tipo de Resolución: Sentencia. Disponível em http://www.poderjudicial. es/search/doAction?action=contentpdf\&databasematch=AN\&r eference $=6479261 \&$ links $=\% 22327 / 2012 \% 22 \% 20$ MARIA $\% 20$ TERESA\%20GARCIA\%20QUESADA\&optimize=20120830\&p ublicinterface $=$ true, acesso em 07/10/2012.

ESTADOS UNIDOS DA AMÉRICA. USAToday Journal, 4/23/2007 10:46 AM. DNA should clear man who served 25 years. Disponível em http://usatoday30.usatoday.com/news/nation/2007-04-22-dnaexoneration-inside_N.htm, acesso em 23/10/2012.

FERNANDES, Antonio Scarance. Prova e sucedâneos da prova no processo penal. Revista Brasileira de Ciências Criminais, n.66, Editora Revista dos Tribunais, Ano 15, maio-junho de 2007.

FERNANDES, Antônio Scarance. ALMEIDA, José Raul Gavião de. MORAES, Maurício Zanoide de. (Coordenadores). Provas no Processo Penal: estudo comparado. São Paulo: Saraiva, 2011.

\section{GAZETA DO POVO ON LINE. Tragédia na Praia dos Amores}

em Caiobá. Disponível em http://www.gazetadopovo.com.br/ vidaecidadania/conteudo.phtml?tl=1\&id $=853179 \&$ tit $=$ Tragediana-Praia-dos-Amores-em-Caioba, acesso em 02/10/2012. 
GIACOMOLLI, Nereu José e DI GESU, Cristina Carla - As Falsas

Memórias na Reconstrução dos Fatos pelas Testemunhas no

Processo Penal - Trabalho publicado nos Anais do XVII Congresso

Nacional do CONPEDI. Realizado em Brasília - DF, nos dias 20,

21 e 22 de novembro de 2008.

GOMES, Luís Flávio, CERVINI, Raúl. Interceptação Telefônica: Lei no

9.296, de 24.07.96. São Paulo: Editora Revista dos Tribunais, 1997.

GRINOVER, Ada Pellegrini, FERNANDES, Antonio Scarance, GOMES FILHO, Antonio Magalhães. As Nulidades no Processo Penal, .6. ed. rev., ampl. e atual. com nova jurisprudência e em face da Lei 9.099/95 e das leis de 1996. São Paulo: Editora Revista dos Tribunais, 1997.

GUIMARÃES, Maurício Henrique et al. Provas Policiais Insuscetíveis de Repetição. Revista da Associação dos Delegados de Polícia do Estado de São Paulo. Marcos Antônio Gama (Coord.), São Paulo: ADPESP. Ano 19, n. 26, dez/99.

ITÁlIA. Codice de Procedura Penale. Disponível em http://www. brocardi.it/codice-di-procedura-penale/libro-terzo/titolo-iii/capoiv/art267.html, acesso em 07/10/2012.

JOHNSON, Wanda B. Eyewitness Identification of Offenders: state-of-art survey and research recommendations. Law Enforcement Assistance Administration. Washington D.C: U.S. Department of Justice, 1973.

LOPES JR, Aury. Direito Processual Penal. - 9. ed. rev. e atual. - São Paulo: Saraiva, 2012.

. Reforma Processual Penal e o Reconhecimento de Pessoas: entre a estagnação e o grave retrocesso. Boletim IBCCRIM : São Paulo, ano 17, n. 200, p. 16-17, julho 2009.

LOPES JR, Aury. DI GESU, Cristina Carla. Falsas Memórias e Prova Testemunhal no Processo Penal: em busca da redução de danos. Revista de Estudos Criminais. Instituto Transdisciplinar de Estudos Criminais. ano VII. n. 25. abr./jun. 2007.

LOPES, Mariângela Tomé. O Reconhecimento como Meio de Prova: necessidade de reformulação do direito brasileiro. Tese (Doutorado em Direito Processual). Faculdade de Direito. Universidade de São Paulo-USP, São Paulo. Orientador: Antônio 
Scarance Filho. 2011. Disponível em http://www.teses.usp.br/teses/ disponiveis/2/2137/tde-10092012-160242/pt-br.php.

LOPES, Mariângela Tomé. O reconhecimento de pessoas e coisas como um meio de prova irrepetível e urgente. Necessidade de realização antecipada In Boletim IBCCRIM. São Paulo: IBCCRIM, ano 19, n. 229, p. 06-07, dez., 2011.

MARSHALL, James. Law and Psychology in Conflict. Garden City, New York: Anchor Books. Doubleday \& Co., Inc., 1969.

MARTINÉZ, Sara Aragoneses e outros. Derecho Procesal Penal. Nueva edición, 30 de junio de 1999. Completada y actualizada. Madrid :Editorial Centro de Estudios Ramón Areces, S.A., 1999.

PORTUGAL. Código de Processo Penal. Decreto-Lei no 78/87, de 17 de Fevereiro, disponível em http://www.pgdlisboa.pt/pgdl/ leis/lei_mostra_articulado.php?nid=199\&tabela=leis, acesso em 07/10/2012.

PORTUGAL. Tribunal da Relação de Coimbra. No Convencional: 486/07.2. GAMLD.C1 JTRC Relator: GOMES DE SOUSA Descritores: PROVA POR RECONHECIMENTO PROIBIÇÃO DE VALORAÇÃO DE PROVAS Data do Acordão: 05/05/2010. Votação: UNANIMIDADE. Tribunal Recurso: COMARCA DA MEALHADA Texto Integral: $S$ Meio Processual: RECURSO PENAL. Decisão: CONFIRMADA. Legislação Nacional: $\mathbf{1 4 7}^{\circ}, 355^{\circ}$ DO CPP. Disponível em http:// www.dgsi.pt/jtrc.nsf/c3fb530030ealc61802568d9005cd5bb/55 466d6aa2c66c848025772a0035046f ?OpenDocument, acesso em 07/10/2012.

PORTUGAL. Tribunal da Relação de Coimbra. No Convencional: 209/09.1PBFIG.C1 JTRC. Relator: PAULO GUERRA. Descritores: PROVA POR RECONHECIMENTO. Data do Acordão: 10/11/2010. Votação: UNANIMIDADE. Tribunal Recurso: COMARCA DA FIGUEIRA DA FOZ - $3^{\circ} \mathrm{J}$. Texto Integral: S. Meio Processual: RECURSO PENAL. Decisão: CONFIRMADA. Legislação Nacional: ARTIGO $147^{\circ}$ DO CPP. Disponível em http://www.dgsi.pt/jtrc.nsf/8fe0e606d8f56b2 2802576c0005637dc/8fa09bd5c06877aa802577ee0041e7f1?Open Document, acesso em 07/10/2012. 
PORTUGAL. Tribunal da Relação de Coimbra. No Convencional: 1582/04.3TBVIS.C1. JTRC. Relator: ELISA SALES Descritores: PROVA POR RECONHECIMENTO DE PESSOAS. Data do Acordão: 06/05/2009. Votação: UNANIMIDADE. Tribunal Recurso:. COMARCA DE VISEU - 20 J. Texto Integral: S. Meio Processual: RECURSO PENAL. Decisão: REVOGADA. Legislação Nacional: ARTIGOS 1470 DO CPP. Disponível em http://www.dgsi.pt/jtrc.nsf/ c3fb530030ea1c61802568d9005cd5bb/ca88b9c730ebb885802575 be0039c450? OpenDocument\&Highlight=0,M\%C3\%89TODOS, PROIBIDOS,DE,PROVA. Acesso em 07/10/2012.

ROBERTS, Andrew. Eyewitness Identification Evidence: procedural developments and the ends of adjudicative accuracy. International Commentary on Evidence. Volume 6, Issue 2. 2009 Article 3. United Kingdom, Berkeley, 2009. Disponível em http://wrap. warwick.ac.uk/887/, acesso em 23/10/2012.

RUIZ, Juan Saavedra. QUIROGA, Jacobo López Barja de. Ley de Enjuiciamiento Criminal: comentada, con jurisprudencia sistematizada y concordancias. Madrid : Colección Tribunal Supremo. El Derecho, 2012.

SAAD, Marta. O Direito de Defesa no Inquérito Policial. São Paulo : Editora Revista dos Tribunais, 2004.

SCHOTT, Richard D.. Warrantless Interception of Communications. Law Enforcement Bulletin, January 2003. Volume 72. Number 1. United States. Department of Justice. Federal Bureau of Investigation. Washington, DC.

SCHUSTER, Beth. Police Lineups: Making Eyewitness Identification More Reliable. National Institute of Justice Journal, n. 258. October 2007. Disponível em http://www.nij.gov/journals/258/ police-lineups.html\#note1, acesso em 23/10/2012.

TONINI, Paolo. A Prova no Processo Penal Italiano; tradução de Alexandra Martins, Daniela Mróz - São Paulo : Editora Revista dos Tribunais, 2002. 
URUGUAI. Ministerio del Interior. Ley de Procedimiento Policial (Ley n ${ }^{\circ} 18.315$ de 5 de julio de 2008 - Código de conducta para funcionarios encargados de hacer cumplir la ley - Adaptado por la Asamblea General de las Naciones Unidas en su resolución 34/169, de 17 de diciembre de 1979);

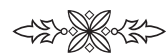

